\title{
AUTHOR INDEX FOR VOLUME 89
}

ABAWAJY, J., KELAREV, A. V., MILLER, M. and RYAN, J.; Incidence semirings of graphs and visible bases

ACCIARRI, C., SHUMYATSKY, P. and THILLAISUNDARAM, A.; Conciseness of coprime commutators in finite groups

AKBARI, S. and HEYDARI, F.; The regular graph of a noncommutative ring

AYAD, M., BELGHABA, K. and KIHEL, O.; On permutation binomials over finite fields

BALLESTER-BOLINCHES, A. and EZQUERRO, L. M.; On conjugacy of supplements of normal subgroups of finite groups

BALLESTER-BOLINCHES, A., BEIDLEMAN, J. C. and ESTEBANROMERO, R.; Primitive subgroups and PST-groups

BANIČ, I. and SOVIČ, T.; Inverse limits in the category of compact Hausdorff spaces and upper semicontinuous functions

BARNES, D. W.; Character clusters for Lie algebra modules over a field of nonzero characteristic

BARRETO, A. P. and FONTENELE, F.; Some remarks on the Pigola-RigoliSetti version of the Omori-Yau maximum principle

BEIDLEMAN, J. C.; see BALLESTER-BOLINCHES, A.

BELGHABA, K.; see AYAD, $M$.

BHARANEDHAR, V. and PONNUSAMY, S.; Remarks on the univalence criterion of Pascu and Pascu

BONANNO, G., HEIDARKHANI, S. and O'REGAN, D.; Nontrivial solutions for Sturm-Liouville systems via a local minimum theorem for functionals

BOURGEOIS, G.; Property L and commuting exponentials in dimension at most three

BRZDĘK, J.; A hyperstability result for the Cauchy equation

CHAOPRAKNOI, S., PHONGPATTANACHAROEN, T. and RAWIWAN, P.; The natural partial order on some transformation semigroups

CHEN, Y.-G. and TANG, C.-E.; Improved upper bounds for odd multiperfect numbers

COSSEY, J.; Special maximal subgroups of $p$-groups

CRAVEN, T. C. and SMITH, T. L.; Symmetric algebras over rings and fields

CRIVEI, S.; Neat and coneat submodules of modules over commutative rings

DE FALCO, M., DE GIOVANNI, F., MUSELLA, C. and TRABELSI, N.; Groups whose proper subgroups of infinite rank have finite conjugacy classes

DE GIOVANNI, F., MARTUSCIELLO, M. and RAINONE, C.; Locally finite groups whose subgroups have finite normal oscillation

DE GIOVANNI, F.; see DE FALCO, M.

DENG, M. J.; A note on the Diophantine equation $(n a)^{x}+(n b)^{y}=(n c)^{z}$

DITTMER, S. J., KHURANA, D. and NIELSEN, P. P.; On a question of Hartwig and Luh

ELGINDY, K.; Gegenbauer collocation integration methods: advances in computational optimal control theory 
ESTEBAN-ROMERO, R.; see BALLESTER-BOLINCHES, A.

EXNER, G. R., JUNG, I. B., LEE, M. R. and PARK, S. H.; Backward 3-step extensions of recursively generated weighted shifts: a range of quadratic hyponormality

EZQUERRO, L. M.; see BALLESTER-BOLINCHES, A.

FECHNER, W.; On a question of J. M. Rassias

FLAMMANG, V.; Comparison of measures of totally positive polynomials $\quad 265$

FONTENELE, F.; see BARRETO, A. P.

GHORAISHI, S. M.; On noninner automorphisms of finite nonabelian $p$-groups 202

GUEST, S., PREVITALI, A. and SPIGA, P.; A remark on the permutation representations afforded by the embeddings of $\mathrm{O}_{2 m}^{ \pm}\left(2^{f}\right)$ in $\operatorname{Sp}_{2 m}\left(2^{f}\right)$

HADWIN, D. and LI, W.; The similarity degree of some $C^{*}$-algebras

HEIDARKHANI, S.; see BONANNO, G.

HEYDARI, F.; see AKBARI, S.

HILLMAN, J. A.; The $\mathbb{F}_{2}$-cohomology rings of $\mathbb{S o l}^{3}$-manifolds

HIRSCHHORN, M. D. and SELLERS, J. A.; Arithmetic properties of 1-shell totally symmetric plane partitions

HONG, S.; see QIN, X.

HUANG, J.; Forecasting wind and solar energy on short time scales

HUMPHRIES, P.; On the Mertens conjecture for elliptic curves over finite fields

JENNINGS, E., POLLACK, P. and THOMPSON, L.; Variations on a theorem of Davenport concerning abundant numbers

JONES, G. A.; Primitive permutation groups containing a cycle

JOSHI, V. and KHISTE, A.; Complement of the zero divisor graph of a lattice

JUNG, I. B.; see EXNER, G. R.

KANNAM, S. K.; Prediction of fluid slip at graphene and carbon nanotube interfaces

KAUFMANN, U. and MEDRI, I.; Strictly positive solutions for one-dimensional nonlinear problems involving the $p$-Laplacian

KELAREV, A. V.; see ABAWAJY, J.

KHISTE, A.; see JOSHI, V.

KHURANA, D.; see DITTMER, S. J.

KIHEL, O.; see AYAD, M.

KISS, S. Z., ROZGONYI, E. and SÁNDOR, C.; Sets with almost coinciding representation functions

KONG, Q. and LIU, Q.; Correction to 'Conjugacy class size conditions which imply solvability'

LANSKI, C.; Finite higher commutators in associative rings 503

LEE, M. R.; see EXNER, G. R.

LEPPÄLÄ, E. and NIEMENMAA, M.; A solvability criterion for finite loops $\quad 92$

LI, C. H. and RAO, G.; Self-complementary vertex-transitive graphs of order a product of two primes

LI, C., YANG, N. and TANG, N.; Some new characterisations of finite $p$-supersoluble groups 
LI, H.; On summability conditions for interval maps 308

LIU, Q.; see KONG, Q. $\quad 522$

LI, W.; see HADWIN, D. $\quad 60$

LUKKARINEN, J. and PAKKANEN, M. S.; Correction to 'On the positivity of Riemann-Stieltjes integrals'

MARTUSCIELLO, M.; see DE GIOVANNI, F.

MEDRI, I.; see KAUFMANN, U

MUKWEMBI, S. and VETRÍK, T.; Wiener index of trees of given order and diameter at most 6

MUSELLA, C.; see DE FALCO, M.

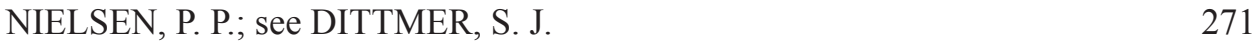

NIEMENMAA, M.; see LEPPÄLÄ, E. 92

O'REGAN, D.; see BONANNO, G.

PAKKANEN, M. S.; see LUKKARINEN, J. $\quad 524$

PAN, H.; A note on the Polignac numbers $\quad 500$

PARK, S. H.; see EXNER, G. R. $\quad 488$

PHONGPATTANACHAROEN, T.; see CHAOPRAKNOI, S. 279

POLLACK, P.; see JENNINGS, E.

PONNUSAMY, S.; see BHARANEDHAR, V. 210

PREVITALI, A.; see GUEST, S. 331

PULS, M. J.; The $p$-harmonic boundary and $\mathrm{D}_{p}$-massive subsets of a graph of bounded degree

QIN, X. and HONG, S.; Constructing permutation polynomials over finite fields $\quad 420$

RAINONE, C.; see DE GIOVANNI, F. 479

RAO, G.; see LI, C. H. $\quad 322$

RAWIWAN, P.; see CHAOPRAKNOI, S. 279

REICH, S. and ZASLAVSKI, A. J.; An example concerning bounded linear regularity of subspaces in Hilbert space

ROZGONYI, E.; see KISS, S. Z.

RYAN, J.; see ABAWAJY, J. 451

SAITO, H. and TANAKA, H.; Directional maximal operators and radial weights on the plane

SÁNDOR, C.; see KISS, S. Z.

SELLERS, J. A.; see HIRSCHHORN, M. D. 473

SHI, W.-X.; see XUAN, W.-F. $\quad 510$

SHPARLINSKI, I. E.; On solutions to some polynomial congruences in small boxes

SHUMYATSKY, P.; see ACCIARRI, C. 252

SILVA, R. P.; A note on resolvent convergence on a thin domain 141

SMITH, T. L.; see CRAVEN, T. C. 466

SOVIČ, T.; see BANIČ, I. $\quad 49$

SPIGA, P.; see GUEST, S. $\quad 331$

TANAKA, H.; see SAITO, H. 397

TANG, C.-E.; see CHEN, Y.-G. 353 
TANG, M.; see XIONG, R. $\quad 460$

$\begin{array}{lr}\text { TANG, N.; see LI, C. } & 514\end{array}$

THILLAISUNDARAM, A.; see ACCIARRI, C. 252

THOMPSON, L.; see JENNINGS, E. 437

TRABELSI, N.; see DE FALCO, M. 41

TRUDGIAN, T.; A new upper bound for $|\zeta(1+i t)| \quad 259$

TRUDINGER, N. S. and ZHANG, W.; Weak continuity of the complex $k$-Hessian operators with respect to local uniform convergence 227

VETRÍK, T.; see MUKWEMBI, S. $\quad 379$

WAN, J. G. F.; Random walks, elliptic integrals and related constants 166

WIŚNICKI, A.; The fixed point property in direct sums and modulus $R(a, X) \quad 79$

XIA, E. X. W. and YAO, O. X. M.; Congruences modulo powers of 2 for Fu's 5 dots bracelet partitions

XIONG, R. and TANG, M.; Unique representation bi-basis for the integers $\quad 460$

XUAN, W.-F. and SHI, W.-X.; A note on spaces with a strong rank 1-diagonal $\quad 510$

$\begin{array}{ll}\text { YANG, N.; see LI, C. } & 514\end{array}$

YAO, O. X. M.; see XIA, E. X. W. 360

YUAN, P. and ZHANG, Z.; Addition to 'An upper bound for the number of odd multiperfect numbers'

YUAN, P.; An upper bound for the number of odd multiperfect numbers 1

ZASLAVSKI, A. J.; see REICH, S.

ZELENYUK, Y. and ZELENYUK, Y.; Counting symmetric bracelets 431

ZELENYUK, Y.; see ZELENYUK, Y. $\quad 431$

ZHANG, W.; see TRUDINGER, N. S. 227

ZHANG, Z.; see YUAN, P. 5

ZUDILIN, W.; A generating function of the squares of Legendre polynomials $\quad 125$ 


\section{INFORMATION FOR AUTHORS}

The Bulletin of the Australian Mathematical Society aims at quick publication of original research in all branches of mathematics. To ensure speedy publication, only articles which are sufficiently well presented, able to be published without revision, and which are judged by the Editor (often in consultation with an Associate Editor) to be competitive are refereed. This policy is in the interests of authors, as a quick rejection is better than a slow rejection. The Bulletin receives more than five times the material that can be published, therefore there are many commendable papers not accepted. Editorial decisions on acceptance or otherwise are taken quickly, normally within a month of receipt of the paper. Papers are accepted only after peer review.

Manuscripts are accepted for review with the understanding that the same work is not concurrently submitted elsewhere. For a paper to be acceptable for publication, not only should it contain new and interesting results, but also

(i) the exposition should be clear and attractive, and

(ii) the manuscript should be in publishable form, without revision.

Further information regarding these requirements may be found through our website www.austms.org.au/Bulletin. Authors are asked to avoid, as far as possible, the use of mathematical symbols in the title.

Articles should be prepared in LTEX using $\mathcal{A}_{\mathcal{M}} \mathcal{S}$-LTTEX packages and submitted as a PDF file via our journal management system, at www.austms.org.au/Publications/Submissions/BAustMS. This permits authors to track their papers through the editorial process. Recent versions of $\mathrm{T}_{\mathrm{E}} \mathrm{X}$ are able to produce PDF files directly. A LATEX class file for the Bulletin can be downloaded from the website. Authors who need assistance may email the secretary of the Bulletin at editor@ bulletin.austms.org.au.

Authors are advised to keep copies of all files of the submitted article; the Bulletin will not accept responsibility for any loss.

\section{EDITORIAL POLICY}

1. References. Arrange references alphabetically (by surname of the first author) and cite them numerically in the text. Ensure the accuracy of the references: authors' names should appear as in the work quoted. Include in the list of references only those works cited, and avoid citing works which are in preparation or submitted. Where the work cited is not readily accessible (for example, a preprint) a copy of the article should be included with your submission.

\section{Abstracts.}

1. Each paper must include an abstract of not more than 150 words, which should contain a brief but informative summary of the contents of the paper, but no inessential details.

2. The abstract should be self-contained, but may refer to the title.

3. Specific references (by number) to a section, proposition, equation or bibliographical item should be avoided.

3. Subject Classification and Key Words. Authors should include a few key words and phrases and one or more classification numbers, following the American Mathematical Society 2010 Mathematics Subject Classification for all codes. Details of this scheme can be found on the web at www.ams.org/msc.

4. Abstracts of PhD Theses. The Bulletin endeavours to publish abstracts of all accepted Australasian $\mathrm{PhD}$ theses in mathematics. One restriction, however, is that the abstract must be received by the Editor within six months of the degree being approved.

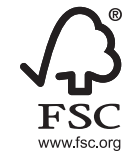

This journal issue has been printed on FSC-certified paper and cover board. FSC is an independent, non-governmental, not-for-profit organisation established to promote the responsible management of the world's forests. Please see www.fsc.org for information. 


\section{Table of Contents}

Improved upper bounds for odd multiperfect numbers

Chen, Y.-G. \& Tang, C.-E.

Congruences modulo powers of $\mathbf{2}$ for Fu's $\mathbf{5}$ dots bracelet partitions

Xia, E. X. W. \& Yao, O. X. M.

Primitive subgroups and PST-groups

Ballester-Bolinches, A., Beidleman, J. C. E Esteban-Romero, R.

Wiener index of trees of given order and diameter at most 6

Mukwembi, S. E Vetrík, T.

Directional maximal operators and radial weights on the plane

Saito, $H$. \& Tanaka, $H$.

Special maximal subgroups of $p$-groups

Cossey, 7 .

Constructing permutation polynomials over finite fields

Qin, X. E Hong, $S$.

Counting symmetric bracelets

Zelenyuk, 1 . E Zelenyuk, $x$.

Variations on a theorem of Davenport concerning abundant numbers

Jennings, E., Pollack, P. E Thompson, $L$.

Incidence semirings of graphs and visible bases

Abawajy, 7., Kelarev, A. V., Miller, M. \& Ryan, J.

Unique representation bi-basis for the integers

Xiong, $R$. \& Tang, $M$.

Symmetric algebras over rings and fields

Craven, T. C. \& Smith, T. L.

Arithmetic properties of $\mathbf{1}$-shell totally symmetric plane partitions

Hirschhorn, M. D. \& Sellers, 7. A.

Locally finite groups whose subgroups have finite normal oscillation

de Giovanni, F., Martusciello, M. \& Rainone, C.

Backward 3-step extensions of recursively generated weighted shifts:

a range of quadratic hyponormality

Exner, G. R., fung, I. B., Lee, M. R. \& Park, S. H.

On a question of J. M. Rassias

Fechner, $W$.

A note on the Polignac numbers

Pan, $H$.

Finite higher commutators in associative rings

Lanski, $C$.

A note on spaces with a strong rank 1-diagonal

Xuan, W.-F. \& Shi, W.-X.

Some new characterisations of finite $\boldsymbol{p}$-supersoluble groups

Li, C., Yang, $\mathcal{N}$. \& Tang, $\mathcal{N}$.

\section{Corrigendum/Erratum}

Gorrection to 'Conjugacy class size conditions which imply solvability'

Kong, Q. \& Liu, Q.

Correction to 'On the positivity of Riemann-Stieltjes integrals'

Lukkarinen, f. \& Pakkanen, M. S.

Author Index for Volume 89 